\title{
AMPLIAÇÃO DA TOMOGRAFIA SÍSMICA NO MANTO SUPERIOR NO SUDESTE E CENTRO-OESTE DO BRASIL COM ONDAS P
}

\author{
Marcelo Peres Rocha \\ Orientador: Dr. Marcelo Sousa de Assumpção (IAG/USP) \\ 71 p - Dissertação (Mestrado) - Defesa 20.08.2003
}

\begin{abstract}
RESUMO. Variações dos tempos de percurso de fases P e PKP foram usados para tomografia sísmica do manto superior sob o sudeste e centro-oeste do Brasil. Os principais objetivos foram: melhorar a resolução obtida pelos estudos anteriores (VanDecar et al., 1995; Escalante, 2002; Schimmel et al., 2003, feitos de 1992 a 2001) com a inclusão de novos dados e estações, mapear as áreas que não tinham sido cobertas pelas estações anteriores, tentar mostrar a consistência da base de dados, principalmente relacionada às novas estaçõese verificar a robustez das anomalias encontradas. Fopi estudada a influencia das estações localizadas nas regiões anômalas através de inversões secundárias (retirando estações). Nesta base foram incluídos registros recentes do ano 2002 e também registros de 2000 e 2001 para eventos utilizados nos trabalhos anteriores. Os resultados confirmaram as estruturas observadas nos trabalhos anteriores e também revelaram novas regiões anômalas, particularmente no Sul do estado de Mato Grosso. Das anomalias observadas nos trabalhos anteriores, confirmamos em nossos resultados o Cráton do São Francisco como uma anomalia de alta velocidade, com suas raízes chegando a $250 \mathrm{~km}$ de profundidade, a anomalia de baixa velocidade interpretada como resto fóssil da pluma de Tristan da Cunha (VanDecar et al. 1995), a boa correlação das anomalias rasas de baixa velocidade com as intrusões alcalinas do Cretáceo Superior (Schimmel et al. 2003), a anomalia de baixa velocidade inferida por Escalante (2002) na região de Iporá em Goiás (possível região do impacto inicial da pluma de trindade), uma anomalia de alta velocidade sob a região da Bacia do Paraná (profundidades rasas) interpretada inicialmente por Schimmel et al. (2003) como possível núcleo cratônico da Bacia do Paraná e também, nesta mesma região (maiores profundidades), uma anomalia de alta velocidade interpretada como a listosfera subduzida da placa de Nazca (Schimmel et al., 2003 e escalante, 2002). A nova base permitiu a expansão da área de estudo e o imageamento de anomalias de baixa velocidade litosférico proposto no modelo de Thompson et al. (1998).
\end{abstract}

ABSTRACT. Variations of $\mathrm{P}$ and PKP travel times were used for seismic tomography of the upper mantle beneath southeast and central Brazil. Our principal objectives were: To improve the resolution obtained by the previous studies (carried out by VanDecar etal., 1995; Escalante, 2002; Schimmel et al., 2003 between 1992 and 2001) with inclusion of new data and stations, to map areas not covered by previous stations, to show the consistency of the database, mainly of the related to the new stations and to verify the robustness of the detected anomalies. The influence of the stations located in the anomalous areas was studied through secondary inversions (removing stations). The new data set includes recent records of 2002 and also new records from 2000 and 2001 for events used in the previous works. Our results confirm the structures observed in the previous works and also revealed new anomalous regions, particularly in the south of the Mato Grosso state. We confirmed the anomalies observed in the previous works: The São Francisco cráton has as a high-velocity anomaly, with roots down to $250 \mathrm{~km}$ depth, the low velocity anomaly interpreted as a fossil remnant of the Tristan da Cunha plume (VanDecar et al. 1995), the good correlation of the shallow low velocity anomalies with the alkaline intrusions of the Late-Cretaceous (Schimmel et al. 2003), the low velocity anomaly inferred by Escalante (2002) in the Iporá igneous province in Goiás (possible area of the initial impact of the plume of Trindade), a high-velocity anomaly under the Paraná Basin (shallow depths) interpreted initially by Schimmel et al. (2003) as possible cratonic nucleus of the Paraná Basin and also, in this same area (larger depths), a high-velocity anomaly interpreted as the slab of the Nazca Plate (Schimmel et al., 2003 and Escalante, 2002). The new data set allowed the expansion of the study area and the imaging of low velocity anomalies in the igneous province of Poxoréu in Mato Grosso, which are consistent with the model of litospheric thinning proposed by Thompson et al. (1998). 